\title{
Nitrogen fertilization induced drought tolerance in sunflower: a review
}

\author{
Shahzadi Mahpara ${ }^{{ }^{*}}$, Muhammad Shahnawaz ${ }^{2}$, Khadija Rehman ${ }^{3}$, \\ Tahira Batool Qaisarani ${ }^{4}$, Riaz Ahmad ${ }^{5}$ and Fahim Ullah Khan ${ }^{6}$ \\ 1. Department of Plant Breeding \& Genetics, Ghazi University, Dera Ghazi Khan-Pakistan \\ 2. Department of Plant Breeding \& Genetics, Bahauddin Zakariya University, Multan-Pakistan \\ 3. National Institute for Biotechnology and Genetic Engineering, Faisalabad-Pakistan \\ 4. Department of Agri. Engineering \& Technology, Ghazi University, Dera Ghazi Khan-Pakistan \\ 5. Department of Horticulture, Bahauddin Zakariya University, Multan \\ 6. Department of Agriculture, Hazara University, Mansehra-Pakistan \\ *Corresponding author's email: smahpara@gudgk.edu.pk \\ Citation \\ Shahzadi Mahpara, Muhammad Shahnawaz, Khadija Rehman, Tahira Batool Qaisarani, Riaz Ahmad and Fahim \\ Ullah Khan. Nitrogen fertilization induced drought tolerance in sunflower: a review. Pure and Applied Biology.Vol. \\ 8, Issue 2, pp1675-1683. http://dx.doi.org/10.19045/bspab.2019.80110
}

\begin{tabular}{llll}
\hline Received: 28/12/2018 & Revised: 30/05/2019 & Accepted: 20/06/2019 & Online First: 24/06/2019 \\
\hline \hline
\end{tabular}

\section{Abstract}

Drought is one of the most common abiotic stresses that badly effect plant growth, causes yield losses. Sunflower requires less water and thus has the capability to survive under drought stress condition. A drought stress condition affect various plant processes reducing plant growth, lessen the developmental stages of cell and tissues, and causes many changes in physiological, morphological and biochemical processes. Nitrogen is the major nutrient among all the nutrients because of its multifarious effects on crop development and production. Many primary processes in plant are governed by nitrogen like nutrient uptake, metabolism of protein, photosynthetic behavior, carbon division and various enzymatic as well as hormonal actions. Studies showed that reduced nutrient uptake and nutrient deficiencies inhibit the normal function of plant in dry soils. Many techniques have been used worldwide to compete with the nutrient scarcity in drought stress. To reduce the unfavorable influences of drought, nitrogen application through soil or by foliar in sunflower is recommended for obtaining higher yield.

Keywords: Drought; Nitrogen response; Plant growth; Physiological processes

\section{Introduction}

Sunflower (Helianthus annuus L.) is one of the most important oilseed crops containing high level of unsaturated fatty acids [1]. Sunflower seed is the most vital source of edible oil by means of a globally production of 33.3 million tons proposed approximately to oil taking out, facilitating $8.5 \%$ for entire globe's amount after soybean, rapeseed and peanut. Sunflower is predominantly sensitive to water scarcity at germination stage. While in arid as well as semi-arid areas, production of sunflower and its yield constancy is inhibited due to water stress. Due to drought on sunflower root length, plant height, grain numbers and dry matter per plant has been reported to reduce [2, 3]. Moreover, significant decline in development of seed, yield related traits and oil contents of sunflower is caused by drought [4].

Drought determines the plant will survive successfully or not in the prevailing 
environmental conditions. The unfavorable possessions of drought on development and enlargement of plants are naturally divergent and may influence during plant development. The extent of water stress on sensitivity, adverse environmental conditions, and interlude of plant to water stress varies. It depends upon other linked stress aspects, genetics of crop species and various developmental phases but mainly germination is an important stage of plant subsistence [5]. Interruption in growth and production of plants depends upon reduced or late emergent of seeds [6]. Maximum as well as uniform germination is achieved by sowing of healthy seeds. Enhanced development and superior yield could be attained under stress when seeds are treated with plant growth regulators that affect germination [7].

One of the universal limiting factors is drought for existence and enlargement of vegetation which confines seed production, maturity, severity of the possessions relies about kind of plants, their maturity period, amount and duration of drought faced by plants. Initially main sensitive stage in life of plant is germination stage. So, drought not only affects germination of seed but also increases time required for germination of plants [6].

Some researchers suggested that some physiological and other plant traits as exaggerated by drought consist of decline in root length, plant height, yield, total biomass per plant and photosynthetic rate [7], while others scientists confirmed that relative water contents extensively lower down below drought state that was related with a lesser photosynthetic rate [8]. Adverse drought could be consequence in declining of photosynthesis, plant death and metabolic interruption [9].

Problems in uptake of water and nutrients under drought conditions require to be evaluated on time to avert yield losses. In drought conditions, application of nutrients to soil is less desirable and effective because of its lowed mobility in the soil. In such situation, other substitute means for application of fertilizer like water run, split side covering and application of foliar can be helpful. Crop need cannot be fulfilled by application of macronutrients like nitrogen and foliar spray. Where nutrient availability through soil nutrient supply is restricted so, additional appliance of Nitrogen fertilizer as foliar is very necessary.

\section{Drought stress and plant growth}

Globally farming has the largest stipulate for water. During 2010, whole agriculture water distribution was $70 \%$, as measure up to $10 \%$ for household utilization and $20 \%$ for industry [10]. During the period crops plant bother short-term drought of altering degrees below watered form due to water shortage. Drought is the reason of number of injurious effects on crop development. Few harmful effects are painted in subsequent passage. In the life span of a crop germination of a seed is the most significant and liable phase. Sunflower being an important oil seed crop predominantly sensitive to lack of water at germination period. While with increasing water scarcity means germination time also increased [11]. Furthermore, many varieties of sunflower expressed different reply for every drought treatments. Detrimental response of drought at germination and seedling development has also been expressed in diverse crops especially in sunflower [12], sorghum [13], sugar beet [14] and wheat [15]. Different cultivars of sunflower expressed multifarious reactions to water stress [16]. Many reports showed flowering is the sensitive stage as compared to other growth stages and watered applied at this phase gives maximum production [17]. Rinaldi [18] determined main serious time(s) of water necessity for sunflower crop. They accounted that to get the better production of sunflower water in gat flowering, milking 
and heading stages are good for crop. Photosynthesis slows down due to water shortage and causes stomata close and metabolic injury [19]. A change in photosynthetic ability of various cultivars under altered water availability has been observed in sunflower [20].

Tahir and Mehdi [21] reported a considerable decline in biomass creation in sunflower below drought; although, a few cultivars in this learning expressed maximum drought tolerances formed comparatively extra amount. Less amount production for a time has a slight reaction on final production for the reason that time of compact development might generate some physiological procedure so as to really enhance production below stress environment [22]. The influence of drought on crop growth and development finally direct decrease in production. They demonstrated decrease in production and production mechanism of sunflower below drought. Due to enhance in drought ultimately decline in yield and yield constituent occurs in sunflower [23]. Tahir et al. [24] found reduction in various plant traits as well as yield and its related traits in 25 varieties of sunflower under water stress. The influence of drought on production and production components rely lying on duration, rigorousness, and period of the drought.

Nel et al. [25] observed with the beginning of scarcity of water increase in water stress causes the reduction in oil percentage in sunflower [26]. Due to increase in water shortage oil percentage decrease in sunflower at various stages ranges from 41-81\% [27]. Petcu et al. [28] changes in fatty acids composition is due to water stress although saturated fatty acids are less influenced by drought as like others. Baldini et al. [29] reported that percentage of unsaturated fatty acids increased due to stress at grain filling period intypical cultivars. Quality of oil as well as drought tolerance can be improved by the application of ABA under water shortage conditions in sunflower crop.

\section{Drought tolerance mechanism}

Compete with low water level in soil crop plants face the structural alterations in osmotic adjustment, stomatal regulation, reduced growth as a result of drought different genotypes express different tolerances in response to drought. Few of regulations are given below.

\section{Stomatal regulation}

Photosynthetic activity in plants is directly affected by Drought. The reason is that reduction in carbon incorporation and metabolism during photosynthesis in various plants along with relative water contents as well as water potential of leaves. Under drought circumstances, plant develops defense mechanism by which excitation energy is consumed by plant leaves instead of photosynthesis carbon metabolism [30]. Intensity and duration of drought determines rate of photosynthesis in crop plants. Extended time develops water stress reduce the plant growth, turgor pressure, reduction in cell division and cell enlargement. Reduction in plant growth occurs in such sunflower genotypes having major turgor pressure under drought conditions [16]. Drought decreased the gas exchange activity because of stomatal and non-stomatal conditions [31]. However, Nawaz et al. [32] revealed important enhance in rate of photosynthetic activity and stomatal conductance of Se-treated wheat plants. In this case, activation of antioxidants and maintaining turgor pressure is mainly due to application of Se on crop plants.

\section{Osmotic adjustment}

Angadi and Entz [16] stated genetically differences concerning leaf osmotic regulation due to stress in sunflower. They indicate that tall cultivars of sunflower are lees drought tolerant than dwarf cultivars expressing less decline in leaf osmotic potential in reaction to drought [33]. 
Accommodated reactions of leaf water characters toward drought were fairly compared within sunflower lines. Leaf osmotic status relies upon the nature and harshness of environmental stress. In some cases, cotton, sunflower, wheat and barley are important as (GB) glycinebetaine accumulators [34].

Proline a low molecular weight compound produce as the result of drought play a function in abiding possessions of stress, maintain the protein and membrane structure under [35, 36]. Plants adaptation under drought is due to proline which acts as particular element in adaptation to trigger numerous reactions and it is a dependable factor for environmental stresses [36]. Studies showed that increased proline production due to drought or salt stress also tolerates this stresses [37].

Amino acids and protein metabolism is related to adjustment of plants to abiotic stresses. On the other hand, there are few different evidences showing less raise up of amino acids in free form when water shortage occurred [38]. Soluble proteins reduced in sunflower due to drought were found by [39]. Dehydrins maintains large molecules in the cell by chaperone similar to characteristics and serve like matchable solutes [40].

Under drought conditions, a function in the order of nitrate reductase and speed up NR gene's transcription are important [41]. Patakas et al. [42] observed insignificant comparison in sugar components in drought and normal grapevine plants. Maintenance of turgor, increasing stomatal conductance, enhancing accumulation of osmo-protectants was found to be effective due to combined effect of $\mathrm{NK}_{\mathrm{c}}$ and it results in higher yield in drought. Under drought conditions activation of antioxidant machinery and accumulation of osmo-protectants are the prime defense mechanisms in plants [38]. Drought severely affected the yield and its related traits in sunflower hybrids which can be predictable by reduced turgor and gaseous exchange and antioxidant activities which caused reduced photosynthates production under water shortage [34].

\section{Nutrients availability under drought}

Fageria et al. [43] depicted that nutrients deliverance toward plants is intimately associated with soil humidity. Within species drought effects on nutrient uptake are different. Crops growing under drought stress condition utilization and absorption of nutrients like nitrogen are very critical for plant growth and yield. A depression is caused by water stress by uptake of nutrients especially phosphorus and nitrogen which are related to decrease yield $[43,44]$. Capability of roots to acquire water from soil is the response of availability of nitrogen fertilizer in any related form. When internal level of water of plant decreases underneath a verge level stomatal closure occur and cause the inhabitation in transpiration ensuring decrease in transport of water in the course of the plant. Due to decrease in plant internal water level capability of plants roots to suck up water and minerals affected as compared to normal transpiration [45]. Drenovsky et al. [46] found drought considerably reduce the productivity of agriculture through decreasing water and nutrients uptake. There is a relationship between water stress and nitrogen responsiveness. Moreover, additional amount of nitrogen played an important role for increased growth and water uptake under shortage of water [46].

Two basic nutrients like nitrogen and potassium play an important role in many biochemical processes like photosynthetic activity and moving of photosynthates from lower part of plant to shoots and leaves, protein synthesis, stomatal opening and closure, water-use effectiveness and controlling the enzymes activities [47].

Nitrogen application under drought

Nitrogen is the essential part of chlorophyll, DNA, RNA and some further molecules 
perform vital part in cell functions. They viewed due to nitrogen inadequacy photosynthesis lower down and cause the decrease in chlorophyll components and rubisco action. The related outcomes also expressed by [48]. Under high fertility situations presentation of plants was good at every point underneath diverse intensities of drought. Undesirable response of drought on desiccated substance and development in pearl millet were reduced by appliance of nitrogen [49, 50]. Because of nitrogen deficiency decrease in leaf growth, single leaf area and entire leaf area was also viewed by [51].

Adequate supply of nitrogen enhances the metabolic procedure as well as vegetative and reproducibility [52]. Klein et al. [41] reported leaf area index (LAI), number of tillers, net absorption rate (NAR), relative growth rate (RGR) and plant yield in wheat was increased at booting and tillering by application of nitrogen.

Fernandez and Eichert [53] revealed nitrate reductase have acknowledged maximum interest and expressed decline in drought effected leaves of sunflower plant. Drought initiated nitrogen shortage for the period of the vegetative stage is able of reason for programmed cell death and growth. Grain maturation period reduced at grain development stage because of nitrogen deficiency. Method which regulate the foliar stuff uptake have been considered in detail as progress of minerals addicted to the plant throughout the leaves entail dissimilar mechanism toward minerals transfer into roots [54]. Mainly in plants profuse cuticles of leaves, which are layered with oily coating building diffusion of solution complicated. Foliar fertilizers to be consume by the crop for enlargement, the minerals have to initially go through the surface of leaf before ingoing a cell cytoplasm inside leaf. There is continuing discuss these diffusion trail participate the significant part in uptake of minerals [55]. Nutrients when applied directly to soil during this phase will be fewer efficient. Under drought conditions, grain yield and protein percentage in grains can be increased through foliar application of urea. Initial flowering, complete flowering, and pod bearing period enhanced pods number and production by urea foliar fertilization in soybean reported by Ling and Silberbush [56]. The area of leaf, production and fresh and dry weight of corn and sweet corn increases by using NPK as a foliar in different states. Sabahi and Rahimian [57] stated that height of plant, tillers numbers per plant, straw production and financial production increases in wheat by nitrogen foliar application. Similarly, Haverkort and Mackerron [58] studied wheat crop and concluded that enhanced spike weight as well as weight of stem is due to $\mathrm{N}$ foliar application.

When nitrogen in form of urea is applied to plants into foliar state, it will reduce the nitrogen losses in environment and for optimum N management [59]. So, concentration of urea is serious for its foliar spray application in different crops plants. Urea and thiourea foliar application increases yield, growth, and oil content and harvest index reported in Indian mustard [60]. Broccoli head size and weight increased by treating with urea foliar application studied [61]. Foliar spray increases the RWC, dry material (DM), and activity of nitrate reductase (NRA) in maize under drought [62]. Drought in sunflower crop has no effect on nutrients like nitrogen and phosphorus but has significant effect on potassium but effect of folic acid as well as humic acid on 1000seed weight and number of seeds per head was extremely significant. To reduce the severe effects of water stress on productivity and growth of crop plants supplemental foliar application of nutrients is a potential approach. 


\section{Conclusion}

Sunflower is an oil seed crop and has great importance due to good oil quality in developed and least developed countries of the world. High yield under drought prone environment is most important global challenge. Drought decrease photosynthetic rate, stomata conductance, evaporation rate and leaf water substance, chlorophyll substance and devastation of some physiological procedure which finally diminish plant enlargement and maturity. Better management of plant nutrients in sunflower could amplify drought tolerance. Drought tolerance can be improved by better plant nutrition in sunflower through application of nitrogen based fertilizer into soil or by foliar. Due to limited nutrients supply to soil additional application of nitrogen as foliarsprayis significant.

\section{Authors' contributions}

Conceived and designed the experiments: $\mathrm{S}$ Mahpara, Performed the experiments: M Shahnawaz, Analyzed the data: K Rehman \& TB Qaisarani, Contributed materials/ analysis/ tools: R Ahmad, Wrote the paper: FU Khan.

\section{References}

1. Madany M \& Khalil R (2017). Seed priming with ascorbic acid or calcium chloride mitigates the adverse effects of drought stress in sunflower (Helianthus annuus L.) seedlings. The Egyptian $J$ of Exper Biol 13(1): 119-133.

2. Mahpara S, Bashir MA, Kamaran S, Irfanullah M, Salman S, Khan FU, Shah Z, Amanullah \& Shahnawaz M (2019). Genetic response of diverse sunflower genotypes in contrasting moisture regimes for various physiological and growth parameters at early developmental stage. Pure Appl Biol 8(1): 820-837.

3. Ahmad S, Ahmad R, Ashraf MY \& Waraich EA (2009). Sunflower (Helianthus annuus L.) response to drought stress at germination and seedling growth stages. Pak J Bot 41: 647-654.

4. Alahdadi I, Hussein $\mathrm{O}$ \& Khajani FP (2011). Effect of water stress on yield and yield components of sunflower hybrids. African J Biotechnol 10: 65046509

5. Demirevska K, Zasheva D, Dimitrov R, Simova-Stoilova L, Stamenova M \& Feller U (2009). Drought stress effects on Rubisco in wheat: changes in the Rubisco large subunit. Acta Physiolo Plantarum 31(6): 1129-1138.

6. Willenborg CJ, Gulden RH, Johnson EN \& Shirtliffe SJ (2004). Germination characteristics of polymer-coated canola (L.) seeds subjected to moisture stress at different temperatures. Agron J 96(3): 786-791.

7. Piri M, Mahdieh MB, Olfati JA \& Peyvast G (2009). Germination and seedling development of cucumber are enhanced by priming at low temperature. Inter J Vegetable Sci 15(3): 285-292.

8. Kumar RR, Karajol K \& Naik GR (2011). Effect of polyethylene glycol induced water stress on physiological and biochemical responses in pigeon pea (Cajanuscajan L. Millsp.). Recent Res Sci Technol 3(1): 6-12.

9. Reddy AR, Chaitanya KV \& Vivekanandan M (2004). Droughtinduced responses of photosynthesis and antioxidant metabolism in higher plants. J Plant Physiol 161(11): 1189-1202.

10. FAO. 2007. Water use and national rainfall indices. Statistical Year Book 2004. Rome.

11. Midaoui EM, Talouizte A, Benbella M, Serieys H, Griveau Y \& Berville A (2001). Effect of osmotic pressure on germination of sunflower seeds (Helianthus annuиs L.). Helia, 24: 129134. 
12. Mohammad ME, Benbella M \& Talouizete A (2002). Effect of sodium chloride on sunflower (Helianthus annuus L.) seed germination. Helia, 37: 51-58.

13. Gill RK, Sharma AD, Singh P \& Bhullar SS (2002). Osmotic stress-induced changes in germination, growth and soluble sugar content of Sorghum bicolor (L.) Moench seeds. Bulgarian J Plant Physiol 28: 120-125.

14. Sadeghian SY \& Yavari N (2004). Effect of water-deficit stress on germination and early seedling growth in sugar beet. J Agron Crop Sci 190: 138-144.

15. Dhanda SS, Sethi GS \& Behl RK (2004). Indices of drought tolerance in wheat genotypes at early stages of plant growth. J Agron Crop Sci 190(1): 1-6.

16. Angadi SV \& Entz MH (2002). Water relations of standard high and dwarf sunflower cultivars. Crop Sci. 42: 152159.

17. Goksoy AT, Demir AO, Turan ZM \& Dagustu N (2004). Responses of sunflower to full and limited irrigation at different growth stages. Field Crops Res 87: 167-178.

18. Rinaldi M (2001). Application of EPIC model for irrigation scheduling in southern Italy. Agric Water Manage 49: 185-196.

19. Lawson T, Oxborough, K Morison, JIL \& Baker, NR (2003). The response of guard and mesophyll cell photosynthesis to $\mathrm{CO}_{2}, \mathrm{O}_{2}$, light and water stress in a range of species are similar. $J$ Exp Bot 330: 127-138.

20. Germ M, Bercic OU \& Acko DK (2005). The response of sunflower to acute disturbance in water availability. Acta Agric Slov 8: 135-141.

21. Tahir MHN \& Mehdi SS (2001). Evaluation of open pollinated sunflower (Helianthus annuus L.) populations under water stress and normal conditions. Int. J. Agric. Biol., 3: 236238.

22. Smith M, Kivumbi D \& Heng LK (2002). Use of the FAO-CROP-WAT model in deficit irrigation studies. Deficit irrigation practices, FAO Water Reports No. 22.

23. Khan A, Iqbal M, Ahmad I, Iqbal N \& Hussain M (2000). Effect of different water stress levels on yield and oil contents of sunflower (Helianthus annuus L.) cultivars. Pak J Biol Sci 3: 1632-1633.

24. Tahir, M.H.N., Imran, M. \& Hussain, M.K., 2002. Evaluation of sunflower (Helianthus annuus L) inbred lines for drought tolerance. Inter J Agric Biol 3: 398-400.

25. Nel AA, Loubser HL \& Hammes PS (2001). The effect of water stress during grain filling in the yield and processing quality of sunflower seed. South African J Plant Soil 18: 114-117.

26. Kazi BR, Oad FC, Jamro GH, Jamali L \& Oad NL (2002). Effect of water stress on the growth, yield and oil content of sunflower. Pak J Appl Sci 2: 250-252.

27. Kaker AA \&Soomro, AG (2001). Effect of water stress on the growth, yield and oil content of sunflower. Pak J Agric Sci 38: 73-74.

28. Petcu E, Arsintescu A \& Stanciu D (2001). The effect of drought stress on fatty acid composition in some somanian sunflower hybrids. Romanian J Agric Res 15: 39-42.

29. Baldini M, Giovanardi R \& Vannoza G (2000). Effect of different water availability on fatty acid composition of the oil in standard and high oleic sunflower hybrids. In: Proceedings of XV InternationalSunflower Conference, Toulouse, Winnipeg, Canada: 79-84.

30. Chaves MM, Pereira JS, Maroco J, Rodrigues ML, Richardo CP, Osorio MLI, Carvalho FT \& Pinheriro C (2002). 
How plants cope with water stress in the field: Photosynthesis and growth. Annals Bot 89: 907-916.

31. Dulai S, Molnar I, Pronay J, Csernak A, Tarnai R \& Molnarlang M (2006). Effects of drought on photosynthetic parameters and heat stability of PSII in wheat and in Aegilops species originating from dry habitats. Acta Biol Szeged 50: 11-17

32. Nawaz F, Ashraf M, Ahmad R, Waraich EA, Shabbir RN \& Bukhari M (2015). Supplemental selenium improves wheat grain yield and quality through alterations in biochemical processes under normal and water deficit conditions. Food Chem 175: 350-357.

33. Nishimura N, Zhanjg J, Abo M, Okubo A \& Yamazaki S (2001). Application of capillary electrophoresis to the simultaneous determination of betaines in plants. Anal Sci 17: 103-106.

34. Bajji M, Lutts S \& Kinnet JM (2001). Water deficit effects on solute contribution to osmotic adjustment as a function of leaf ageing in three durum wheat (Triticum durum Desf) cultivars performing differently in arid conditions. Plant Sci 160: 669-681.

35. Ozturk L \& Demir Y (2002). In vivo and in vitro protective role of proline. Plant Growth Regulation 38: 259-264.

36. Maggio A, Miyazaki S, Veronese P, Fujita T, Ibeas JI, Damsz B, Narasimhan ML, Hasegawa PM, Joly RJ \& Bressan RA (2002). Does proline accumulation play an active role in stress-induced growth reduction. The plant J 31(6): 699-712.

37. Claussen W (2005). Proline as a measure of stress in tomato plants. Plant Sci 168: 241-248.

38. Hsu SY, Hsu YT \& Kao CH (2003). The effect of polyethylene glycol on proline accumulation in rice leaves. Biol Plantarum 46: 73-78.
39. Rodriguez JD, Romero-Garcia JD, Rodriguez-Garcia R \& Sanchez JLA (2002). Characterization of proteins from sunflower leaves and seeds. Relationship of biomass and seed yield. In: Trends in New Crops and New Uses, eds. Janick J, Whipkey A \& Alexandria VA: ASHS Press 143-149.

40. Hoekstra F, Golovina E \& Buitink J (2001). Mechanisms of plant desiccation tolerance. Trends Plant Sci 8: 431-438.

41. Klein D, Morcuende R, Stit M \& Krapp A (2000). Regulation of nitrate reductase expression in leaves by nitrate and nitrogen metabolism is completely overridden when sugars fall below a critical level. Plant Cell Environ 23: 863-871.

42. Patakas A, Nikolaou N, Zioziou E, Radoglou K \& Noitasakis B (2002). The role of organic solute and ion accumulation in osmotic adjustment in drought-stressed grape-wines. Plant Sci163: 361-367.

43. Fageria NK, Baligar VC \& Clark RB (2002). Micronutrients in crop production. Adv Agron 77: 185-167.

44. Warraich EA, Ahmed N, Basra SMA \& Afzal I (2002). Effect of nitrogen on source-sink relationship in wheat. Inter $J$ Agric Biol4: 300-302.

45. Du NW, Zhang GX \& Wang R (2010). Morphological and physiological responses of Vitexn egundo L. var. heterophylla (Franch.) Rehd to drought stress. Acta Physiol Plant 32: 839-848.

46. Drenovsky RE, Grewelland BJ \& Dantonio CM (2012). A functional trait perspective on plant invasion. Ann Bot 110: 141-153.

47. Salami M \& Saadat S (2013). Study of potassium and nitrogen fertilizer levels on the yield of sugar beet in jolge cultivar. J Appl Sci 2: 94-100.

48. Toth VR, Meszkaros I, Veres S \& Nagy J (2002). Effect of the available nitrogen 
on the photosynthetic activity and xanthophylls cycle pool of maize in field. J Plant Physiol 159: 627-634.

49. Ashraf M, Shehbaz M \& Ashraf MY (2001). Influence of nitrogen supply and water stress on growth and nitrogen, phosphorous, potassium and calcium contents in pearl millet. Biologia Planterum 44: 459-462.

50. Lawlor DW (2002). Carbon and nitrogen assimilation in relation to yield mechanisms are the key to understanding production systems. J Exp Bot 53: 773 787.

51. Silva AJ, Osorio J, Fonseca F \& Correia MJ (2004). Effects of soil drying and subsequent re-watering on the activity of nitrate reductase in root and leaves of Helianthus annuus. Functio Plant Biol 31: 611-621.

52. Eichert $\mathrm{T} \&$ Burkhardt J (2001). Quantification of stomatal uptake of ionic solutes using a new model system. J Exp Bot 52: 771-787.

53. Fernandez V \& Eichert T (2009). Uptake of hydrophilic solutes through plant leaves: Current state of knowledge and perspectives of foliar fertilization. Crit Rev Pl Sci 28: 36-68.

54. Jairo AP, Nandwal AS, Kumari $S$ \& Turner NC (2005). Foliar nitrogen applications increase the seed yield and protein content in Chickpea (Cicer arietinum L.) subject to drought. Aust J Agric Res 56: 1-8.

55. Oko BFD, Eneji AE, Binang W, Irshad $\mathrm{M}$, Yamamoto $\mathrm{S}$, Honna $\mathrm{T} \&$ Endo $\mathrm{T}$ (2003). Effect of foliar application of urea on reproductive abscission and grain yield of soybean. J Plant Nutri 26:
1223-1234.

56. Ling F \& Silberbush M (2002). Response of maize to foliar vs. soil application of nitrogen, phosphorouspotassium fertilizers. J Plant Nutri11: 2333-2342.

57. Sabahi H \& Rahimian H (2000). The effect of pre and post anthesis foliar spray of urea on leaf area duration and protein contents of two wheat cultivars. J Agric Sci 6: 65-77.

58. Haverkort AJ \& Mackerron DKL (2000). Management of Nitrogen and Water in Potato Production. Wageningen, Netherlands, Wageningen Press.

59. Sharma PP \& Jain NK (2003). Effect of foliar sprays of agrochemicals on growth and yield of Indian mustard (Brassica juncea). Indian J Agric Sci 73: 381-383.

60. Yildirim E, Guvenc I, Turan M \& Karatas A (2007). Effect of foliar urea application on quality, growth, mineral uptake and yield of broccoli (Brassica oleracea L., var. italica): Plant Soil and Environ 53: 120-128.

61. Zhang LX, Sheng XL, Zong SL \& Shi QL (2009). Effect of foliar nitrogen application on nitrogen metabolism, water status, and plant growth in two maize cultivars under short-term moderate stress. J Plant Nutri 32: 18611881.

62. Zhang L, Li S, Liang Z \& Li S (2009). Effect of foliar nitrogen application on nitrogen metabolism, water status, and plant growth in two maize cultivars under short- term moderate stress. $J$ Plant Nutri 32(11): 1861-188. 